\title{
Ordering Africa
}

Antbropology, European imperialism, and the politics of knowledge

EDITED BY HELEN TILLEY

WITH ROBERT J. GORDON

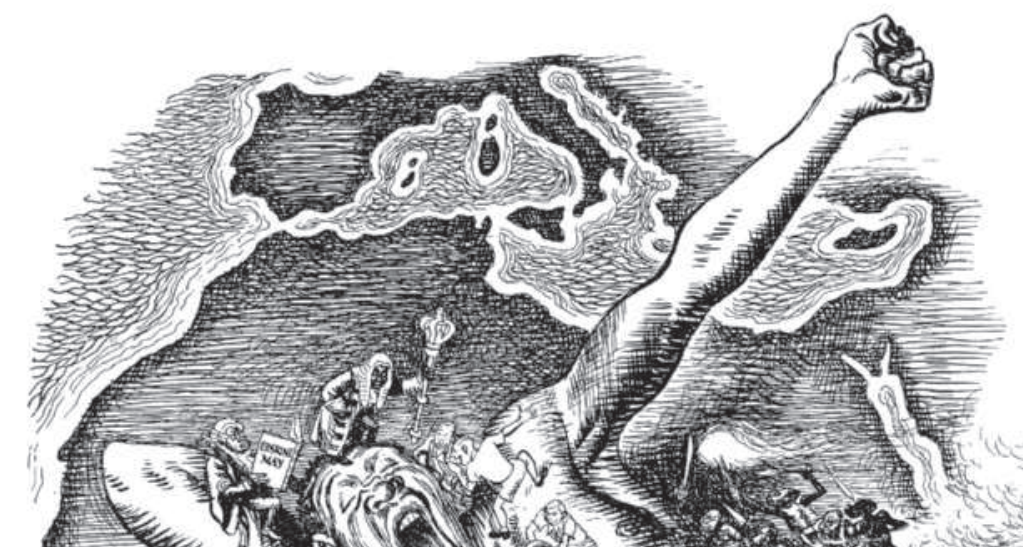

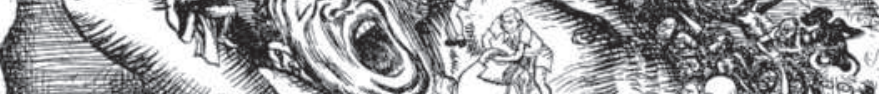

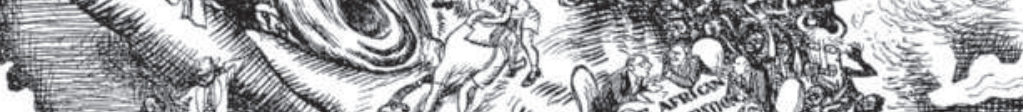

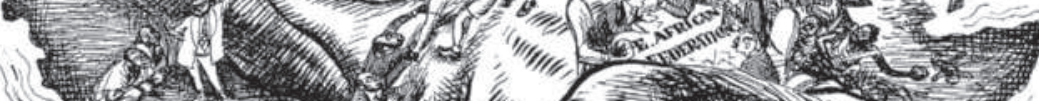
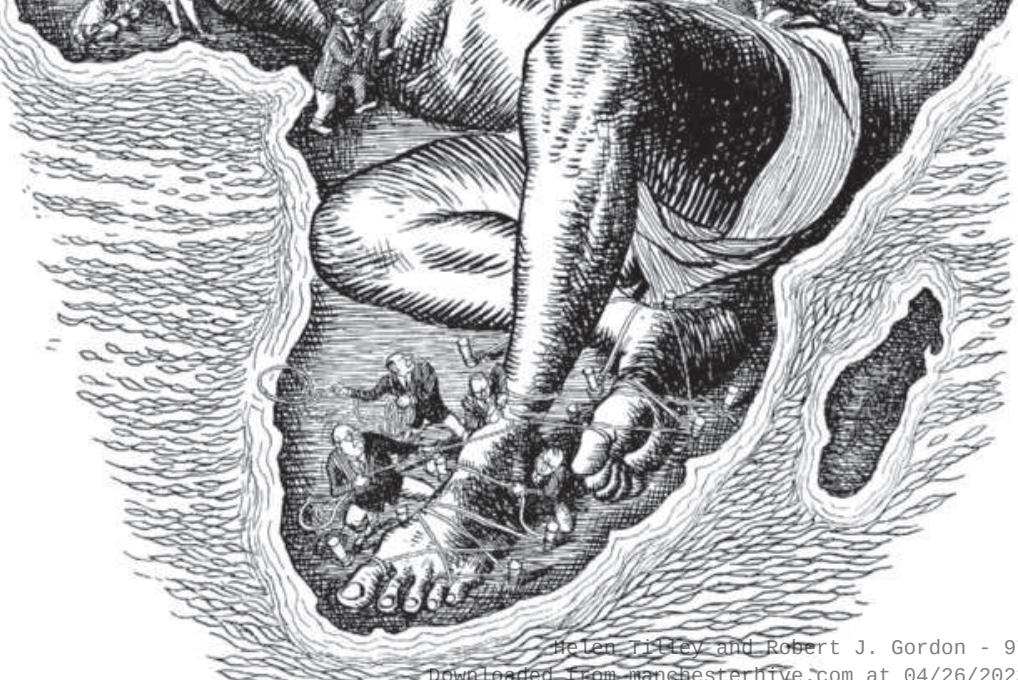


\section{-STUDIES IN- \\ IMPERIALISM}

general editor John M. MacKenzie

When the 'Studies in Imperialism' series was founded more than twenty years ago, emphasis was laid upon the conviction that 'imperialism as a cultural phenomenon had as significant an effect on the dominant as on the subordinate societies'. With more than sixty books published, this remains the prime concern of the series. Cross-disciplinary work has indeed appeared covering the full spectrum of cultural phenomena, as well as examining aspects of gender and sex, frontiers and law, science and the environment, language and literature, migration and patriotic societies, and much else. Moreover, the series has always wished to present comparative work on European and American imperialism, and particularly welcomes the submission of books in these areas. The fascination with imperialism, in all its aspects, shows no sign of abating, and this series will continue to lead the way in encouraging the widest possible range of studies in the field. 'Studies in Imperialism' is fully organic in its development, always seeking to be at the cutting edge, responding to the latest interests of scholars and the needs of this ever-expanding area of scholarship.

\section{Ordering Africa}

\section{MANCHESTER 1824}

Manchester University Press 
Helen Tilley and Robert J. Gordon - 9781526118714 Downloaded from manchesterhive.com at 04/26/2023 09:37:39AM 


\section{Ordering Africa}

Anthropology, European imperialism, and the politics of knowledge

Helen Tilley with Robert J. Gordon

MANCHESTER UNIVERSITY PRESS

Manchester 
Copyright (c) Manchester University Press 2007

While copyright in the volume as a whole is vested in Manchester University Press, copyright in individual chapters belongs to their respective authors, and no chapter may be reproduced wholly or in part without the express permission in writing of both author and publisher.

Published by Manchester University Press

ALTRINCHAM STREET, MANCHESTER M1 7JA, UK

Www.manchesteruniversitypress.co.uk

British Library Cataloguing-in-Publication Data is available

Library of Congress Cataloging-in-Publication Data is available

ISBN 9780719082122 paperback

First published by Manchester University Press in hardback 2007

This paperback edition first published 2010

The publisher has no responsibility for the persistence or accuracy of URLs for any external or third-party internet websites referred to in this book, and does not guarantee that any content on such websites is, or will remain, accurate or appropriate. 